\title{
Literary Modernism, Anti-Semitism, Jewishness and the Anxiety of Assimilation in Interwar Hungary
}

\section{Dávid Szolláth}

Abstract: In this paper I will provide a brief overview of early twentieth-century, Hungarian history in order to examine how anti-Semitism and anti-modernism influenced modernism's reception in fin- de- siècle Hungary. In 1908 the most significant Hungarian literary review of the twentieth century was founded by Hugo Ignotus, Miksa Fenyő and Ernő Osvát, all of whom were assimilated Jews. The journal's title, Nyugat, ['West'] unambiguously marked the editors' orientation and program of accelerating cultural modernization by reviewing and translating Western European works. For conservatives this aim of transferring aestheticism, late Symbolism and decadence was regarded as an attack against the nation's patriotic traditions. Anxiety surrounding the Jewry's purported "failed assimilation" was compounded by the fear that a foreign culture would have an undue impact on Hungarian literature. It is my aim to analyze both the first and second wave of modernism in Hungary so as to reveal the analogous relationship between the argument that Western European modernism is alien to the Hungarian literary style and language and the anti-Semitic argument stating that assimilation of the Jews is superficial.

Keywords: Modernism, Anti-Semitism, Assimilation, Anxiety of Assimilation, Nyugat, Tibor Déry, Lajos Kassák, Miklós Szentkuthy

Biography: David Szolláth (Ph.D.) is the editor of the literary and critical review, Jelenkor ['Present Time'] (Pécs) as well as a Research Fellow at the Research Center for Humanities, Institute of Literary Studies (Budapest) for the Hungarian Academy of Sciences. Szolláth researches twentieth-century Hungarian literature and is the author of $A$ kommunista aszketizmus esztétikája, ['The Aesthetics of Communist Ascetism'] (Budapest, 2011) a volume analyzing the labor movement's impact on Hungarian literary thinking from the early nineteen-twenties to the nineteen-fifties. He is currently writing a monograph about the Hungarian author, Miklós Mészöly (1921-2002). dszollat@yahoo.com

In the beginning of the twentieth century, deviancy and the breaking of norms was often connected to the alien. Breaking aesthetic and linguistic norms was therefore viewed as a mark of being both a social and ethnic outsider, someone whose work was incompatible with the aesthetic set of norms dictated by national classicism, the mainstream doctrine of the time that called for language, art and literature to be the rightful representative of the national character. In Hungary, national classicism resulted from a great and fruitful period of nation building that took place in the nineteenth century, as described by analysts of European nationalism such as Ernest 
Szolláth, Dávid. "Literary Modernism, Anti-Semitism, Jewishness and the Anxiety of Assimilation in Interwar Hungary." Hungarian Cultural Studies. e-Journal of the American Hungarian Educators Association, Volume 10 (2017) DOI: 10.5195/ahea.2017.296

Gellner (1983) and Benedict Anderson (1991). Standardizing Hungarian as a national tongue, discovering folk music and codifying the aesthetic rules defining art forms such as historical painting, opera-music or poetry were all aspects of this push to establish the cultural identity of a nation politically dependent upon the Habsburg Empire. Speaking in Hungarian rather than German or Latin, writing poetry in Hungarian, or singing Hungarian folksongs in public were subsequently viewed as brave gestures of freedom. The fact that this process of establishing a Hungarian national identity extended to include the assimilation of non-Hungarian groups explains why Hungarian nationalism remained liberal for most of the nineteenth century.

As mainstream Hungarian society endeavored to build a nation within the uneven circumstances produced by the Dual Monarchy, a period of assimilation emerged as an attempt to encourage non-Hungarian minorities (including individuals of Jewish, German, or Slovak origin) to accept a Hungarian identity. At the time, assimilating into the majority, Hungarian culture was the accepted means of establishing a nation out of a multi-ethnic society. In exchange, Hungarian society granted the possibility of social mobility to individuals originating from non-Hungarian groups. In practice, however, this process proved far more complex.

For Jews, it was emancipation in 1867 that initiated their assimilation into Hungarian society. However, beginning at the turn of the twentieth century and peaking in the years following World War I, anti-Semitism grew increasingly fervent in Hungarian politics and society. This historical process is best summarized by the binary concepts put forth by the Hungarian-Australian historian Vera Ranki: policies aimed at the inclusion of Hungarian Jews were replaced by their exclusion from society (Ranki 1991). The marginalization of the Jewish minority increased in the nineteen-twenties and nineteen-thirties before leading to the "ultimate exclusion" exacted by the Holocaust in the nineteen-forties. Still liberal in the nineteenth century, Hungarian nationalism therefore became increasingly conservative as well as racist in the twentieth century.

When, however, in the first decades of the twentieth century a group of writers and critics dared to suggest that Western European, modernist poetry should be translated into Hungarian, their attempt was interpreted as an insult to the traditions of national classicism and they were labeled traitors by conservative journalists. While modernism also emerged out of a clash between conservative and progressive in other nations throughout Europe, within Hungary this conflict was rendered particularly bitter due to the social process of assimilation occurring in the backdrop of this cultural movement. Since many modernist writers, artists, and journalists were of Jewish ancestry, it was easy for conservatives to claim that modernists had turned their backs on Hungarian tradition and were promoting the foreign examples offered by modernist, Western literature because they served alien (i.e., Jewish) interests.

In this paper I will discuss the role anti-Semitism played in defining the reception of modern Hungarian literature. Before doing so I must first differentiate between the two waves of modernism that determined modern Hungarian literature. The first wave is typically regarded as the literature of aestheticism, a movement numbering symbolism and decadence among its main characteristics. The emblematic periodical for this literary endeavor was entitled Nyugat [West]. The second wave consisted of an avant-garde movement spearheaded by the "Activists," a group led by the poet and artist, Lajos Kassák who also edited the literary reviews A tett ['Action'] and $M a$ ['Today']. While both Nyugat and avant-garde writers indulged in heated debates concerning the other's approach, each group promoted the translation and reception of contemporary Western literature. 
Szolláth, Dávid. "Literary Modernism, Anti-Semitism, Jewishness and the Anxiety of Assimilation in Interwar Hungary." Hungarian Cultural Studies. e-Journal of the American Hungarian Educators Association, Volume 10 (2017) DOI: 10.5195/ahea.2017.296

The development of modernism contains interrelated components of social history, the history of political ideas as well as literary history. To understand the connection between antimodernism and anti-Semitism, it is first necessary to examine certain demographic questions originating in the nineteenth century. Already a part of a multi-ethnic empire, the Habsburg Monarchy, Hungary was in itself a multi-ethnic nation containing a citizenry more than half of which was not Hungarian. In 1880 only forty-six percent of the population found in the Kingdom of Hungary was ethnic Hungarian. The majority was formed from the following groups, listed in the order of their population percentage: Jewish, German, Slovak, Romanian, Serbian, Croatian, and Ukrainian. By 1900 the population's composition had changed to such an extent that by 1910, fifty-four percent of the population considered itself Hungarian. This new, absolute majority of Hungarians over other ethnic groups was made possible through the assimilation of a non-Orthodox, Jewish population (Hanák 1984: 358-359). Due to the fact that the Non-Orthodox Jews chose to claim themselves as native speakers of Hungarian in the census, they were considered a religious rather than an ethnic group. From this point on, assimilated Jews were designated as "Hungarians of Israelite faith," a decision that tipped the balance slightly in favor of the Hungarian community. This "correction" in population statistics was not the only advantage attained via assimilation for Hungarians of the time; as Ranki described it: "Jews were needed to fill the role of the middle class, necessary for economic modernization" (Ranki 1991: 1). In short, this economic and social compromise formed the basis for an unspoken social contract between Hungary's liberal nobility and the emerging Jewish middle class: assimilation provided the basis for coexistence between the two faiths and therefore influenced society and culture favorably. Among the ethnic groups of the period, Jewish and German communities were consequently the most urbanized and educated. Once Hungarian Jews possessed equal rights, their children learned Hungarian, family names were Hungarianized, and the assimilated Jewish community identified itself as Hungarian. Meanwhile, their addition to Hungarian society contributed to economic and financial growth brought about by the establishment of new business enterprises.

In Hungarian culture the turn of the century was a kind of golden age as a new urban intelligentsia emerged in Budapest. This culture was unique due to its nature as a genuine melting pot of assimilating Jewish, German and Hungarian youth. The cultural scene in fin-desiècle Budapest was characterized by the existence of dozens of daily newspapers, an impressive array of literary reviews, a vivid theater life, new tendencies in art galleries and ongoing political and literary debates in every café. Emerging scientific disciplines such as sociology and psychoanalysis found their way to Budapest in no time. According to Péter Hanák, assimilation in Budapest was actually a more successful process than it had been in Vienna due to the fact that the assimilation of Hungarian Jews enjoyed the support of the national liberal movement mentioned above. Creating a modern Hungarian culture was itself a joint project for Jews and Hungarians alike; in Vienna the goal for assimilation was not to build a new nation, but rather to maintain an old, bureaucratic Empire incapable of offering a national identity (Hanák 1984: 366367).

\section{From Inclusion to Exclusion}

Following World War I and the collapse of the Austro-Hungarian Empire, this golden age founded upon the "social contract" reached between the Hungarian elite and Jewish minority came to a sudden end. With the fall of the Habsburg Empire, Hungary lost two-thirds of its 
Szolláth, Dávid. "Literary Modernism, Anti-Semitism, Jewishness and the Anxiety of Assimilation in Interwar Hungary." Hungarian Cultural Studies. e-Journal of the American Hungarian Educators Association, Volume 10 (2017) DOI: 10.5195/ahea.2017.296

territory, the first traumatic event to mark the history of modern Hungary. Hundreds of thousands of families were torn apart while properties and homes were also lost. Industries and railways were suddenly located outside the country, together with formerly Hungarian cities that were suddenly a part of newly founded states ruled by former minorities. Universities, theaters, schools, historic relics and cathedrals all became a part of Romania, Slovakia, Yugoslavia and the Soviet Union. Hungarian nationalism's greatest fear seemed to be coming true: the death of Hungary as a nation was imminent. While this old fear stemmed from the prophesy-originating in Romantic nationalism - that the Hungarian nation would drown in an ocean of German and Slavic masses, following the Treaty of Trianon, this image of national death appeared to be a genuine, historical process happening at high speed and no longer the mere product of Romantic fantasy.

Defeat in World War I and the humiliating peace treaty of Trianon were considered to be either the fault or consequence of treason committed by two revolutionary governments that succeeded one another in 1918 and 1919 respectively. It cannot be denied that many people of Jewish origin were put in power during the two revolutionary governments that ruled the country for some months at the end of the war. Nor can it be denied that many modernist painters, writers, and journalists sympathized with these civil revolutionary parties; Lajos Kassák, for example, was appointed to office and the Nyugat poet, Mihály Babits, accepted a university chair. After the fall of these governments, propaganda promoted by the reactionary and conservative regime of Vice-Regent Horthy made scapegoats of the Jews and of the modern leftwing intelligentsia. The modern capital, Budapest was labeled in right-wing journalism the City of Sin, a kind of modern Sodom and nest of liberalism. (Gyáni 2008: 68-70). The ironic nickname of Judapest spread in the anti-Semite and anti-modernist discourse, which is ironic not only in the first part, changing Buda- to Juda- but, as is less well known today, also refers to German Peste, so that Judapest is not only 'Pest filled with too many Jews' but also 'The Jewish Pestilence' (cf. also French "la Peste juive"). According to propaganda promulgated by the Horthy regime, a foreign, anti-Christian power (the secret Jewish global conspiracy) had allied with Bolshevik Russia in an attempt to destroy Hungary. Other, more profound factors beyond scapegoating contributed to the exclusion of Hungarian Jews. With the loss of two-thirds of its territory, Hungary had also lost its minority groups: "Hungarians of Israelite faith" were therefore no longer a necessary component to tipping the population's ethnic balance.

Once the unspoken contract underlying assimilation was effectively broken by the political elite in Hungary, attempts to discourage assimilation grew increasingly more vocal. The social historian, Gábor Gyáni, (2002) traces the long history of the discourse concerned with "superficial assimilation" in Hungarian historiography. One of the most influential, conservative historians during the interwar period, Gyula Szekfü, stated that Jewish assimilation was, in fact, superficial and therefore could not lead to genuine integration. According to Szekfü, nineteenthcentury Hungarian liberal statesmen had made a grave error in rashly offering legal and economic opportunities to Jews, who in turn achieved economic success and cultural influence far too early and easily and at the expense of the traditional Hungarian landowner ruling class, or dzsentri (which is not totally akin to the word's English origin, 'gentry'), and without themselves becoming Hungarians in heart and soul. László Németh, author of Kisebbségben ['In Minority'], one of the most ill-fated anti-Semitic essays dating from the interwar period, also stated that the initial stages of assimilation (i.e., adopting a new language and leaving behind a former identity) only served as a disguise for Jews. As Németh argued, due to their inherent 
Szolláth, Dávid. "Literary Modernism, Anti-Semitism, Jewishness and the Anxiety of Assimilation in Interwar Hungary." Hungarian Cultural Studies. e-Journal of the American Hungarian Educators Association, Volume 10 (2017) DOI: 10.5195/ahea.2017.296

attraction to cosmopolitism, Jews had clearly not been able to resist the call of internationalism; Jews had therefore been shamelessly avaricious in taking over huge segments of Hungarian politics and culture (Németh 2014: 887; for further contemporary objections surrounding unsuccessful Jewish assimilation, see Kerekes 2008: 179).

During the interwar period, it was assimilated Jews became the main target for antiSemites. Oddly enough, sometimes the more Hungarian a Jew was, the more dangerous he or she appeared. The Yiddish-speaking Orthodox man wearing sidelocks and a kippah as he strolled down Dob Street in the Jewish quarter of Budapest was not viewed as the main problem for the anti-Semitic press. Instead, it was the Hungarian-speaking Jew who had already dropped his forefathers' family name and made a career in Hungary came under fire. While nationalism took a far more liberal stance in the nineteenth-century, the Magyarization of Jews was considered an emancipatory project: when nationalism turned racist, assimilation and the mixing of races was regarded to be the greatest danger.

As was previously mentioned, in the nineteen-twenties and nineteen-thirties, nationalist thinkers like Dezső Szabó or László Németh called the project of assimilation and Magyarization a failure because according to them Hungarian Jewry's new national identity only masked their genuine, evil nature. This is why de-masking and unveiling the "hidden Jew" became perhaps one of the most widespread rhetorical strategies employed by the anti-Semitic press of the time. Journalists went to great pains to print an individual's previous, Jewish family name alongside his or her new Hungarian name when mentioning someone of Jewish origin. Naming became a means of de-masking and thereby branding an individual as foreign. A typical example is the list of names appeared in the right-wing, Jesuit periodical Magyar Kultúra ['Hungarian Culture'] edited by Father Béla Bangha SJ, a highly influential priest who played a key role in the spread of anti-Semitism following World War I (Bihari 2016). Among others, the list contains the names of authors who regularly contributed to the modernist, Nyugat literary review and publishes the individual's former, Jewish name next to his new, Hungarian name. For example, the internationally renowned playwright, Ferenc Molnár, was unmasked by revealing his birth name of Ferenc Neumann. The prominent politician and sociologist Oszkár Jászi was downgraded to Oszkár Jakubovics while the poet and author, Ernő Szép, was listed as Ernő Schön (for full list see: Burján 1917).

The individuals listed were people who had attained great respect and recognition for their work and talent in various areas of Hungarian culture. A list of this kind displays a sort of proto-Fascist logic: it erases any type of differentiating mark among a group of first-rank poets, writers, playwrights, journalists and political thinkers. (See Alphen 2015: 13 for an additional examination of the Nazis' similar penchant for creating lists.) By depriving them of their individuality, the list suggests that these authors possess only one principal feature that rules out all other characteristics: that is, they are all Jews. Questioning the authenticity of their Hungarian names is a denial not only of their nationality but also of their work. In fact, in the first half of the twentieth-century Hungarian Jewish writers mostly came from assimilated families possessing an unquestionably strong sense of Hungarian identity. Most had only faint memories concerning their religious grandfathers or the Passover Seders of their childhood. The poet, playwright and author, Ernő Szép is often quoted for saying - with his typical sense of ironythat his Jewishness was a "sad accident," like an illness one shouldn't talk about in good company (Turi 2013: 181). In 1943, the confessional poet, Miklós Radnóti, who perished in the Holocaust, refused to publish his work in a Hungarian Jewish literary anthology, even though he 
Szolláth, Dávid. "Literary Modernism, Anti-Semitism, Jewishness and the Anxiety of Assimilation in Interwar Hungary." Hungarian Cultural Studies. e-Journal of the American Hungarian Educators Association, Volume 10 (2017) DOI: 10.5195/ahea.2017.296

had already undergone his first round of forced labor, made obligatory for Jewish people in Hungary World War II. At the time, Radnóti stressed that he was a Hungarian writer, not a "Jewish-Hungarian." The Nyugat literary critic, literary historian and prominent researcher of Hungarian Jewish literature, Aladár Komlós, wrote that if there was any common, characteristic feature of "Hungarian Jewish" literature, it would have to be the consistently recurring experience that some Hungarian writers from time to time had to face the fact that they were said to be "Jewish," even though they did not feel themselves to be different from other, non-Jewish Hungarians (Komlós 1997; Turi 2013: 182).

Division between the modernists and the conservatives therefore ran deep and was frequently characterized by a discourse that did not shy away from using race and religion to brand modernist authors with the taint of deviancy, a symptom of their inherently "foreign" origins. Quite ironically, even non-Jewish, modernist authors became tarred with the same brush, as shown by the example of how the conservative press viewed works by the poets, Endre Ady and Mihály Babits. Their names did not figure in the "de-masking" list mentioned above because they were Christians: Ady was Protestant and came from the eastern part of the country, near Transylvania while Babits was a Roman Catholic and from the Transdanubia Region located in the western part of Hungary. Both represented the two main traditions of Hungarian Christianity as well as the two symbolic regions of Hungary itself. This, however, was not enough to deceive the ever-vigilant anti-Semitic press: due to the facts that Ady had a married woman as his mistress, drank heavily, traveled to Paris and had syphilis while Babits wrote a pacifist poem during World War I, both were considered blasphemous imitators of Baudelaire and other immoral Western poets rotten through with venereal disease. Since the editors and the patrons of Nyugat (Ignotus, Ernő Osvát, Lajos Hatvany, Miksa Fenyő) were assimilated Jews, the conservatives employed yet another "unveiling" strategy of interpretation to argue that Ady and Babits acted as the masks for the Jewish face of Nyugat. In short, they were considered by the conservatives as Christians put on display in the storefront window of Nyugat's Jewish emporium.

It is important to mention that even the Hungarian style used by Nyugat authors seemed to be unacceptable for some of its adversaries. The language of Nyugat was said to be "unHungarian, or even "half-Hungarian" by the prominent conservative critic and literary historian, János Horváth (Horváth 1911), who wrote an influential article in 1911 on the linguistic barbarism of the modernists. In this article Horváth connected the poetic language of the modernists to a socially stigmatized, linguistic variant of daily speech found in Budapest, a means of expression peppered with Germanisms and obviously influenced by Yiddish, a form of speech commonly labeled by conservatives as a mannered and arrogant way of speaking. Further examples of how the type of Hungarian language usage found in the capital was labeled as "damaged" and "inferior" in comparison to the "pure" Hungarian spoken in the countryside or Transylvania are provided by Gyáni (1995) and Kontra (2003: 181-183). For János Horváth as well as the less talented conservatives following in his footsteps, breaking linguistic norms and altering standard literary language was not a sign of creativity, but rather the sign of a stranger trespassing in the sacred garden of pure Hungarian.

Horváth's charges against Jewish usage of Hungarian language were not unique and isolated examples in that time. In Prague, another cultural center of the Austro-Hungarian Monarchy, elements of a similar anti-Semitic discourse surrounded the creative work of Franz Kafka. Sander L. Gilman's monograph revealing the effects of anti-Semitic discourse on Kafka's work 
Szolláth, Dávid. "Literary Modernism, Anti-Semitism, Jewishness and the Anxiety of Assimilation in Interwar Hungary." Hungarian Cultural Studies. e-Journal of the American Hungarian Educators Association, Volume 10 (2017) DOI: 10.5195/ahea.2017.296

highlights that assimilation, on a race theory basis, could not be seen other than superficial or simulated: "Jews will never become true Germans; their Germanness is a mere sham" (Gilman 1995: 13). This is also true for the possibilities of cultural and linguistic integration, as can be seen of Gilman's analysis of Kafka's anxieties concerning how even his usage of German could be taken as a telling marker of racial difference (Gilman 1995: 18).

The strategy taken by János Horváth and his followers in Hungary can be interpreted as another variant of the aforementioned demasking strategy commonly found in newspapers stoking the anti-Semitic press. Modern poetry was interpreted not as an innovation, but as a sign of assimilation gone wrong: according to conservative claims, modernist poets had not made sufficient effort to learn the language of the country. In his answer to János Horváth's assertion that the kind of language employed in Nyugat is not Hungarian enough, Ignotus, one of the journal's legendary founders and editors, agreed that the Budapest way of speaking was indeed more exposed to foreign influences, but he claimed that this was a sign of evolution rather than decay (Ignotus 1911). Ignotus proudly stated that the multi-ethnic city with its population of assimilated minorities created its own linguistic variant which was perhaps more modern and therefore more suited to the twentieth-century. Most modernist writers and poets believed that, for example, translation of foreign literary works was the best way to enrich their own poetic language, an aim they attained by creating wonderful, new words via the literal, word-to-word translation of foreign phrases. For conservatives, on the other hand, linguistic interaction meant contamination and was in fact analogous to the perceived social infection brought about by the assimilation into Hungarian society of a minority.

\section{Two Waves of Modernism}

With its liberal, decadent, aesthetic l'art pour l'art stance, Nyugat and the authors it propagated soon became the flagship of modernist Hungarian literature. Nyugat's success, however, led to the emergence of rivals. The first Hungarian avant-gardist review, $A$ Tett ['Action'] was launched seven years after Nyugat, in 1915. While avant-garde authors were initially inspired by Marinetti, Walt Whitman and Apollinaire, Tett, as well as its descendent, $M A$ ['Today'] offered a comprehensive review of Europe's avant-garde trends. The central figure around which this group coalesced was Lajos Kassák; at the time, the members of this group called themselves "New Poets" or "Activists." Since the group was politically left wing and revolutionary, general opinion considered them to be similar to Bolsheviks, anarchists, or even worse. They were thought to be lunatics, and as such naturally posed a danger to society, but were still not considered as harmful as Nyugat, for the avant-gardists did not draw as much attention as Nyugat did. A telling fact is that when a lawyer prepared Kassák for his trial, he advised him to tell the judge that he was a futurist poet, for that would provide enough of an extenuating circumstance (Kassák 1983: 661). While several Hungarian Jews belonged to the avant-gardist movement, Kassák was not Jewish. As far as Kassák’s orgins were concerned, he can be described as a half-Slovak, half-Hungarian metalworker. This circumstance did not keep anti-Semitic critics such as Miklós Nagy from writing that Kassák was attracted by the internationalism and intelligence of the Jews and had therefore assimilated into being Jewish rather than Hungarian (Nagy 1935). This example provides another case of the de-masking strategy, one which easily allows an anti-Semite to stigmatize someone with Jewishness in spite of his or her admittedly non-Jewish origins.

Kassák's first review, Tett, was banned by court order for generating international 
Szolláth, Dávid. "Literary Modernism, Anti-Semitism, Jewishness and the Anxiety of Assimilation in Interwar Hungary." Hungarian Cultural Studies. e-Journal of the American Hungarian Educators Association, Volume 10 (2017) DOI: 10.5195/ahea.2017.296

propaganda against Hungarian interests. According to the court, this review was guilty of inciting anti-Hungarian sentiment by praising art produced by Hungary's military enemies. In short, Tett was seen as a powerful act of provocation against nationalist militarism. As András Kappanyos discussed in his study (2008: 183), it can be said that—by releasing an international special issue of Tett-Kassák and his group proclaimed their international solidarity with modern artists across the globe, a move that was far more important to them than expressing solidarity with their nation was. What Hungarian avant-gardists did echoed similar acts done by the immigrant Dadaists, whose performances and writings were also provocations regarding the very concept of national identity. The 1921 Paris manifesto entitled Dada soulève tout ['Dada Stirs up Everything'] contained, for example, an inscription stating that the manifesto's signatories may live in France, America, Spain and Germany, etc., but they possess no nationality. ("Les signataires de ce manifeste habitent la France, l'Amérique, l'Espagne, l'Allemagne, l'Italie, la Suisse, la Belgique, mais n'ont aucune nationalité" Aragon et al. 1921). Further examples of this type of attitude exist in the Zurich group's multilingual performances and poems, or in the "nomadism" of Dadaist artists like Duchamp, Man Ray, Francis Picabia, Tristan Tzara, Marcel Ianco, or Hans Arp / Jean Arp and Yvan Goll, etc., who spent their careers moving between New York City and Paris. These artists also played with multilingualism on stage or in poems such as Balsam Cartouche by Arp and Tzara:

purgatoire annonce la grande saison
hat sie je mit katzenleim gebuhlt
l'eau du diable pleure sur ta raison
pfau und stern signieren „katapult”

(Tzara 1975: 496)

Just as Tett's special issue proclaimed its "allegiance" to the international, avant-garde movement, the court case that resulted from this provocative gesture represented not only the first scandal to surround the Hungarian avant-garde, but also the event to make their so-called "reputation" in Hungarian society.

Following the communist revolution of 1919, Hungarian avant-gardists were forced to emigrate in order to escape the witch-hunt being carried out under the guise of anti-communism, by the regime that had come to power. At this time nearly a whole generation of liberal and leftist intelligentsia fled the country, including László Moholy-Nagy, Marcel Breuer, Fred Forbáth as well as other young artists who went to Germany and later made a career in the Bauhaus movement. Together with his group, Kassák spent the next six years in Vienna, a period that proved to be the most fruitful one for the $M A$ review since this marked the time when the Hungarian avant-gardist movement became a kind of "full-fledged" member of Europe's avantgarde groups. During their years in Vienna, Lajos Kassák, Tibor Déry as well as others published in both Hungarian and German, a decision that stemmed from the fact that they never abandoned the idea of returning to Hungary, yet still wanted to reach an international audience. Ámokfutó ['Running Amok,' or 'Amokläufer' in German], a major work of Hungarian Dadaism authored by Tibor Déry and consisting of a montage of newspaper cutouts, pictures and poetic texts, was given its own German and Hungarian version, for example. Other than the conservative discourse surrounding assimilation, emigration formed another factor in defining avant-gardist modernism as a movement alien to the Hungarian spirit in the "social imagination." 
Szolláth, Dávid. "Literary Modernism, Anti-Semitism, Jewishness and the Anxiety of Assimilation in Interwar Hungary." Hungarian Cultural Studies. e-Journal of the American Hungarian Educators Association, Volume 10 (2017) DOI: 10.5195/ahea.2017.296

Anti-Semitic fears therefore played a significant role in formulating the reception surrounding both the initial, aesthetic, Nyugat-oriented wave of Hungarian modernity as well as the later, avant-garde wave headed by Lajos Kassák. In order to examine this issue from a more intimate perspective, I would like to discuss three authors possessing different family backgrounds as examples illustrating three paths assimilation could lead to in late nineteenthcentury Hungary. The first author is the aforementioned Lajos Kassák and leader of the Hungarian avant-gardist movement, who came from a half-Hungarian, half-Slovak background. The second is Tibor Déry, who started his career in Nyugat, but later became an avant-gardist poet, writer and playwright. Déry's mother came from an Austrian Jewish family, while his father was a Hungarian Jew. The third is Miklós Szentkuthy, the son of ethnic German parents living in Hungary. While Szentkuthy did not consider himself to be an avant-gardist, nevertheless his early novel, Prae, was the only significant avant-gardist novel in the interwar period in Hungary. Most significantly, all three authors wrote memoirs in which not much was mentioned concerning their non-Hungarian family origins.

Strange as it may seem, in Kassák's memoir, Egy ember élete ['The Life of a Man'] (1983) only a few pages deal with his Slovak father. In comparison, Szentkuthy's memoir (1988) has only a few lines referring to how his parents spoke only very limited Hungarian. The strangest phenomenon of all is Déry's memoir (1971), which says not even a word about his parents' Jewish origins. Instead, Déry describes his beloved mother as being Austrian, and therefore not speaking Hungarian. No traces of these authors' non-Hungarian origins are to be found in their fictional works, either. An influential paper written by the Hungarian philosopher, Ágnes Heller (1997), details the strange practice of erasing traces of Jewishness from Jewish characters in Hungarian fiction. One of her main examples comes from Déry's most famous novel, written after the author's surrealist period, called $A$ befejezetlen mondat ['The Unfinished Sentence'] Originally finished in 1938, this thousand-page work was first published in 1947 and contains an autobiographic narrative describing a family very similar to Déry's own bourgeois background, including sociological characteristics, habits, dress, family issues and shameful secrets. The only missing piece to Déry's representational totality within this whole realist image is that the narrator never mentions the family's easily recognizable Jewishness.

It is my contention that the astonishing way in which Kassák, Déry and Szentkuthy avoid mentioning their non-Hungarian roots is symptomatic of how the nationalist discourse on assimilation could be internalized within separate individuals - independently of whether they were actually Jewish or not. Similarly, it must not be forgotten that for someone from a bilingual family, the very choice of being a Hungarian writer was an act of assimilation. As young men, these individuals chose a language and a culture as a project of their own self-identification. Kassák, Déry, Szentkuthy grew up in a country that established a set a hierarchy among its cultures and languages. Neither Kassák nor anyone else would have had the opportunity to become a Slovak writer: only the Hungarian language allowed Kassák to be published. Szentkuthy, on the other hand, used the Hungarian language to get into university and thereby rise to a higher social status. Déry chose the Hungarian language and cultural identity to free himself from the German-speaking bourgeois world of his factory-owning uncle who became a millionaire while profiting from World War I. It is easy to accept, that for them the cultural otherness of their families was a highly sensitive question, one related to their original choice of self-fashioning, to use Stephen Greenblatt's term. 
Airing his own Jewish, German, or Slovak origins would have rendered a Hungarian writer very vulnerable. In the case of Déry and Szentkuthy, traces of what can be called "assimilation anxiety" are recognizable. When speaking about their relationship to the Hungarian language in their late memoirs published in the nineteen-seventies and nineteen-eighties, both expressed slight feelings of shame. "Mastering foreign languages strengthens, but also weakens a writer." is the comment that Déry voiced in his memoir, Ítélet nincs ['There Is No Judgement'] when recalling the beginning of his career as a writer. The narrator of the memoirs is astonished by how polite his older friends, Ernő Osvát and Árpád Tóth (editor and poet of the Nyugat), were in not warning him that he was speaking and writing improper Hungarian, just as his texts abounded with shallow linguistic elements related to the Budapest way of speaking. He draws the following lesson from his early years as a general advice for debut writers: "If someone's sense of language is imperiled anyway, as was mine coming from an Austrian family from my mother's side, and thus having spent most of my childhood out of Hungary, he should pay twice as much attention to the perils of infection" (Déry 1971: 156). Similar linguistic issues emerge in Szentkuthy's late memoir:

Ha nem tudnék írni, bizony nem lenne csoda, mert családi környezetben nem tanultam semmit, de még szavakat se. Műveimben erőnek erejével kellett felépítenem egy külön nyelvezetet gondolataim kifejezésére. Még ma is néha arra gondolok, hogy úgy jártam az "anyanyelvvel", mint az a gyerek, akit nem tanítottak meg szülei járni: kínjában, hogy ne vegyék észre, megtanul bukfencezni. Elég ritka látvány az utcán bukfencező ember, ugye? én is így vagyok: nem tanítottak meg beszélni, hát stílusbukfencekkel fejezem ki gondolataimat.

It is a wonder I learned to speak at all. In my family I did not learn anything, not even words. In my literary works I had to construct my own private language in a huge effort to express my thoughts. Sometimes I think that my case with my 'mother tongue' is similar to a child who has not been taught how to walk, so instead he painfully learns somersaulting by himself, hoping that no one will notice that he is not able to walk properly. Is not it strange to see someone somersaulting in the street instead of walking? I am just like this man: my parents did not teach me to speak, so I express my thoughts through somersaults of style (Szentkuthy 1988: 60-61. Translated by the author).

Both authors quite obviously felt they had not spoken Hungarian well enough when they left their families and began their literary career and consequently had to catch up to other writers in their linguistic development. At the same time, the fact must be emphasized that both writers created unquestionably modern classics of Hungarian literature. Still, these exceptional masters of the language felt it important to express their anxiety. This type of sentiment can be interpreted as a form of "assimilation anxiety" felt by an individual originating from a stigmatized minority group.

In the case of Hungarian avant-gardists, other than the effective forces of assimilation, yet another, political component made them set aside any questions surrounding their multicultural origins. As a social democrat, Kassák was a committed supporter of modern labor-culture and 
Szolláth, Dávid. "Literary Modernism, Anti-Semitism, Jewishness and the Anxiety of Assimilation in Interwar Hungary." Hungarian Cultural Studies. e-Journal of the American Hungarian Educators Association, Volume 10 (2017) DOI: 10.5195/ahea.2017.296

maintained his own circle, or school for young workers where he was the master teacher. A communist as early as 1918, Déry took part in the Austrian uprising of 1934 during his years abroad. Both viewed racism and anti-Semitism as a manifestation of the state propaganda generated by the Horthy regime; as such, they thought of it as a kind of scapegoating hysteria, the primary goal of which was to avoid addressing genuine social problems, such as the exploitation of the proletariat and the peasantry. In Hungary, left-wing avant-gardists firmly believed that all social, ethnic and religious differences would be erased by the coming revolution. While Nyugat contained articles about Jewish culture and Nyugat authors reflected on anti-Semitism, the Avant-Gardists considered these questions to be debris from the past and therefore not worthy of discussion. In their opinion, neither religion nor their family traditions had any place in a review concerned with the art of the future. This circumstance provides another, alternate interpretation of the surprising lack of Jewish subjects and ethnic minority issues in Hungary's avant-garde reviews - most of which were written by Jewish or ethnically non-Hungarian contributors.

Despite the fact that Kassák, Déry and Szentkuthy did not speak or write much about their non-Hungarian roots, their silence suggests that many questions remain for literary historians to study concerning the effect assimilation may have had on the formation of modernist literature in Hungary. Can some connection be found between modern Hungarian literature's linguistic rule-breaking and the language issues many of its assimilated authors had? One example exists in Ignotus's pride for the "modern" language used in by a multi-ethnic Budapest. The question can also be raised of whether or not coming from a bilingual family bestows writers with the experience of linguistic relativity at an early age, thereby introducing them to the reality that language is not a perfect totality, for the same thing can be named in different ways. As a result of this type of experience, authors possessing this kind of background could have been predisposed to the subversive linguistic practices exhibited in avant-garde poetry. Further comparisons must be drawn in reference to examples such as the following, in which Kassák recalls the mixture of languages his father employed when scolding the boy Kassák for skipping school: "This thing it smack no good to me...you, you fail school! You rascal! You scamp, you fail...crucifixus! Herrgott my father in heaven!” [Nekem ez a dolog nagyon nem smakkolja....hát megbukta maga! Gazember, csirkefogó, megbukta...krucifix! Herrgott miatyánk!]” (Kassák 1983, vol. 1: 14). These grammatically incorrect sentences brimming with Latin and German words not only bespeak of a father who is not fluent in Hungarian, but also foreshadow the future, nonsense lines that enriched Kassák's avant-gardist works with a polyphonic outburst of linguistic creativity: "Ó dzsiramári / Ó lébli / ó Bum Bumm" (Kassák 1969: 100). While it is impossible to know exactly what inspired Kassák’s usage of incomprehensible, made-up words, this untranslatable line of "gobbledygook" above is about as far from Hungarian as Hugo Ball's "Gadji beri bimba" is from German.

It is not difficult to link the effect anti-Semitism had on conservative critics' antimodernist stance during the period when the reviews Nyugat, Tett and MA were launched. The fear of a "failed" or "superficial" assimilation of the Jewry was interconnected to the deep-seated fear of what cultural impact foreign influences would have on Hungarian literature. In the end, the discourse surrounding assimilation affected not only writers of Jewish origin, but also caused anxiety for writers possessing any kind of minority origin. While growing up as the child of an assimilated family certainly meant a social disadvantage for Hungarian authors, this circumstance can perhaps also be viewed as a source of great inspiration for increased linguistic 
Szolláth, Dávid. "Literary Modernism, Anti-Semitism, Jewishness and the Anxiety of Assimilation in Interwar Hungary." Hungarian Cultural Studies. e-Journal of the American Hungarian Educators Association, Volume 10 (2017) DOI: 10.5195/ahea.2017.296

creativity.

\section{Works Cited}

Aragon, Louis et al. 1921. "Dada soulève tout" ['Dada Stirs up Everything'] 1921, Paris https://www.dadart.com/dadaisme/dada/031a-dadasoulevetout.html.

Anderson, Benedict. 1991. Imagined Communities. Reflections on the Origin and Spread of Nationalism. London - New York: Verso.

Bihari, Péter. 2016. "Aspects of Anti-Semitism in Hungary 1915-1918”, QUEST Issues in Contemporary Jewish History. October. http://www.questcdecjournal.it/focus.php?id=377.

Burján, Károly. 1917. "Rövid feljegyzések” [“Brief Notes”] Magyar Kultúra 5.7 (1917): 430431.

Déry, Tibor. 1917. Ítélet nincs. ["Without Judgement"] Budapest: Szépirodalmi Kiadó.

Gellner, Ernest. 1983. Nations and Nationalism. Oxford: Basil Blackwell.

Gilman, Sander L. 1995. Franz Kafka. The Jewish Patient. London - New York: Routledge. Gyáni, Gábor. 1995. "A pesti nyelv" ['The Language of Pest”] A hétköznapi Budapest.

Nagyvárosi élet a századfordulón. ['Everyday Budapest. City Life at the Turn of the century'] Budapest: Városháza, 76-84.

2002. Az asszimiláció fogalma a magyar társadalomtörténetben ['Concept of Assimilation in Hungarian Social History”] In: Történészdiszkurzusok. Budapest: L'Harmattan, 119-133.

- 2008. Budapest - túl jón és rosszon. A Nagyvárosi múlt mint tapasztalat. ["Budapest - Beyond Good and Evil. The City Past as an Experience'] Budapest: Napvilág.

Hanák, Péter. 1984. “A zsidóság asszimilációja a Monarchiában.” ['Question of Jew

Assimilation in the Austro-Hungarian Monarchy'] Zsidókérdés, asszimiláció, antiszemitizmus. Tanulmányok a zsidókérdésröl a huszadik századi

Magyarországon. Budapest: Gondolat Kiadó, 357-379.

Heller, Ágnes. 1997. “Zsidótlanítás a magyar zsidó irodalomban” ['Dejudaization in Hungarian Jewish literature'] Az idegen. ['The Stranger'] Budapest: Múlt és jövő, 158-171.

Horváth, János. 1911. "A Nyugat magyartalanságairól” [“On The Unhungariannesses of the Review 'Nyugat'”] Magyar Nyelv, 8.2: 61-74.

Ignotus. 1911. “A Nyugat magyartalanságairól.” Nyugat, 6.24: 1028-1040.

Kappanyos, András. 2008. Tánc az élen. ["Dance on the Edge"] Budapest: Balassi Kiadó. Kassák, Lajos. 1983. Egy ember élete 1-2. ['A life of a Man'] Budapest: Magvető Kiadó. 1969. Összes versei 1-2. ['Collected Poems'] Budapest: Magvető Kiadó.

Kerekes, Janet. 2008. "Masked Ball at the White Cross Cafe: Introducing a Book about Jewish Emancipation and the Origins of the Holocaust" Hungarian Studies, 35.1-2: 177186.

Kontra, Miklós. (ed.) 2003. Nyelv és társadalom a rendszerváltáskori Magyarországon. ['Language and Society in the Change of Regime Hungary'] Budapest: Osiris.

Komlós, Aladár. 1997. "Egy megírandó magyar-zsidó irodalomtörténet elé.” ['A Forenote to a Hungarian-Jew History of Literature yet to Write'] Magyar-zsidó szellemtörténet a reformkortól a holokausztig II. Bevezetés a magyar-zsidó irodalomba. Budapest: 
Múlt és Jövő, 75-81.

Nagy, Miklós. 1935. "Három író társadalomszemlélete.” ['Three Writers’ View of Society'] Magyar Kultúra 22.7: 413-414.

Németh László. 2014. Kisebbségben ['In Minority'] [1939] A minöség forradalma -

Kisebbségben, Politikai és irodalmi tanulmányok, beszédek, vitairatok, Digitális

Irodalmi Akadémia

Budapest: Petőfi Irodalmi Múzeum.

http://dia.jadox.pim.hu/jetspeed/displayXhtml?docId=0000010998\&secId=0000996 220\&mainContent $=$ true \& mode $=$ html.

Ranki, Vera. 1999. The Politics of Inclusion and Exclusion. Jews and Nationalism in Hungary. New York - London: Holmes and Meier.

Szentkuthy, Miklós. 1988. Frivolitások és hitvallások. ['Frivolities and Creeds'] Budapest: Magvető Kiadó.

Szép, Ernő. 1984. Emberszag. ['The Smell of Humans'] Budapest: Szépirodalmi.

Turi, Tímea. 2013. "Esetlegesség, közvetlenség, naivitás. Szép Ernő Emberszag címü regénye és a zsidó identitás" ['Contingency, Immediacy, Naivety. The Novel 'The Smell of Humans' of Ernő Szép and Jewish Identity'] “Zsidó” identitásképek a huszadik századi magyar irodalomban. Ed. Schein, Gábor - Szücs, Teri. Budapest: ELTE, 181-190.

Tzara, Tristan. 1975. Euvres complètes, tome 1, 1912-1924. Texte établi, présenté et annoté par Henri Béhar, Paris: Flammarion.

van Alphen, Ernst. 2015. "List Mania in Holocaust Commemoration" Revisiting Holocaust Representation in the Post Witness Era. Ed. Popescu, Diana I. - Shult, Tanja. Basingstoke, UK - New York: Palgrave Macmillan, 11-27. 